\title{
Cenozoic stratigraphy in the Danish North Sea Basin
}

\section{P. Konradi}

Geological Survey of Denmark and Greenland, Øster Voldgade 10, DK-1350 Copenhagen Ø, Denmark. Email: pk@geus.dk

Manuscript received: November 2003; accepted: February 2005

\begin{abstract}
This paper provides a concise review of investigations into the Cenozoic stratigraphy of the Danish North Sea Basin. In the Danish North Sea, mainly Pliocene and Pleistocene strata are found. Results of published seismic and sequence stratigraphic analyses are combined with biostratigraphic analyses and correlated to marine formations found onshore.
\end{abstract}

Keywords: Eastern North Sea, Neogene, Pleistocene, sequence stratigraphy

\section{Introduction}

Following the stratigraphic work by Deegan \& Scull (1977) a stratigraphy for the Danish North Sea sector was established by a working group at the Danish geological survey (Kristoffersen $\&$ Bang, 1982). They subdivided the Cenozoic, excluding the Danian, into 6 informal units, where the unit CEN- 5 comprises the Miocene above the mid-Miocene unconformity as well as the Pliocene, and the unit CEN- 6 comprises the Pleistocene to Recent. With the introduction of the sequence stratigraphic concept it was logical to apply it to the sediments of the Danish North Sea. In 1993, a manuscript was published (Michelsen et al., 1998) with a quite comprehensive study including interpretation of seismic data, petrophysical logs and lithology as well as biostratigraphy of the eastern North Sea, primarily the Danish North Sea sector. This study divided the post-Chalk succession into 7 informal 'Major Sequence Stratigraphic Units' (Michelsen, 1996). The major sequences were controlled by shifting sediment sources and available accommodation space in a more or less clock-wise direction (Huuse, 2002). The first 6 major sequences were primarily derived from Scandinavia and from Scotland. The uppermost 'Major Sequence Stratigraphic Unit', no. 7, comprises the 'Nordland Group' of Deegan \& Scull (1979). Apparently, these sediments derive from Scandinavia and from Baltic rivers.

\section{Miocene}

Major Sequence Stratigraphic Unit 7 (Fig. 1) comprises the sediments found above the mid-Miocene unconformity. It was divided into 6 preliminary sequences, the four lower ones are of late Middle Miocene to Pliocene age and the two upper ones of Pleistocene age. The depocenter is located in the Central Graben area and the sequences are lenticular prograding clinoforms migrating towards the west (Sørensen \& Michelsen, 1995). The unit makes up roughly half of the thickness of the post-Chalk succession of sediment in the area.

This Major Unit was later refined and divided into 31 sequences (Sørensen \& Michelsen, 1995). Due to the existence of the Ringkøbing - Fyn High the sequences developed differently in the northern Norwegian-Danish Basin area and in the southern North German Basin area. The two basins were interconnected in the west in the Central Graben area. Apparently more hiatuses exist in the northern area, especially in the upper part. This phenomenon can possibly be caused by the quality of the conventional seismic data and by the lower thickness of the strata or these two causes in combination.

The mid-Miocene unconformity, that forms the base of Unit 7, is a conspicuously strong seismic reflector seen all over the eastern North Sea Basin (Cameron et al., 1993) and is recognised as a marked downlap surface migrating westward in the 


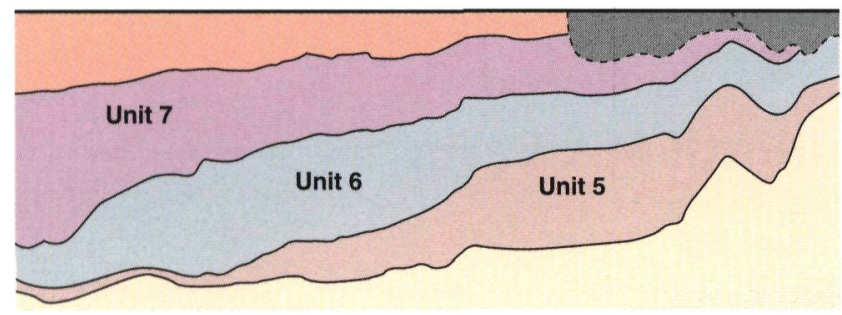

Fig. 1. Interpreted seismic reflection profile from the south to the north through the Horns Graben. Depth about $1 \mathrm{sec}$ TWT and length about $100 \mathrm{~km}$.

Central Graben area (Huuse \& Clausen, 2001). The reflector is seen as an onlap surface migrating eastward in areas with Oligocene and Early Miocene strata on the Ringkøbing-Fyn High. In the gamma ray records it is characterised by one (or two) distinct peaks probably indicating starved sedimentation in the basin during a high-stand (Kristoffersen \& Bang, 1982). It appears to correlate with the Middle Miocene Hodde transgression (Fig. 2), which led to the termination of peat formation in most northwest European lowlands (Huuse, 2002). Onshore Denmark, the marine conditions prevailed and continued in the Gram Formation of late Middle to Late Miocene age (Rasmussen, 1966). This is a coarsening-upward succession of clay and silt probably with sandy intercalations giving rise to a horizontally laminated seismic signature.

\begin{tabular}{|c|c|c|c|c|c|c|c|}
\hline \multicolumn{3}{|c|}{$\begin{array}{l}\text { CHRONO- } \\
\text { STRAT. }\end{array}$} & $\begin{array}{l}\text { MAJOR } \\
\text { SEQUENCE } \\
\text { START.UNITS } \\
\text { (Michelsen } \\
\text { et al. 1998) }\end{array}$ & \multicolumn{3}{|c|}{$\begin{array}{l}\text { LITHOSTRATIGRAPHY } \\
\text { ONSHORE DENMARK } \\
\text { (Michelsen 1996, Michelsen et al. 1998) }\end{array}$} & EAST \\
\hline \multirow{5}{*}{ 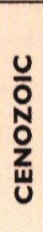 } & QUAT & NARY & \multirow{5}{*}{7} & का & $\mathrm{s}, \mathrm{n}$ & QUATERNAF & \\
\hline & $\begin{array}{l}\text { PLIO- } \\
\text { CENE }\end{array}$ & $\frac{U}{L}$ & & III & & SSE Em & \\
\hline & \multirow{3}{*}{$\begin{array}{l}z_{u}^{u} \\
\frac{\mathrm{g}}{\Sigma}\end{array}$} & $u$ & & $\begin{array}{l}E \\
E \\
E\end{array}$ & $\begin{array}{l}\equiv= \\
\equiv=\end{array}$ & GRAM Fm. & \\
\hline & & \multirow{2}{*}{ M } & & एथाप्या & 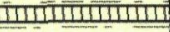 & 1010ण & सापापा \\
\hline & & & & $E$ & $=\bar{z}=$ & HODDE Fm & \\
\hline
\end{tabular}

Fig. 2. Stratigraphic table, with the Formations found in Jylland.

\section{Pliocene}

The existence of Pliocene deposits onshore Denmark is still debated as the so-called Sæd Clay (Fig. 2) is definitely of latest Miocene age (Rasmussen, 1966). In the Central Graben progradational wedges are ascribed to the Pliocene (Huuse 2002). Biostratigraphic investigations in wells in the northern part of the Danish sector (Konradi, 1995, 1996) indicate that the most complete section appears to be found in the Central Graben area. Here in the Kim-1 well only fluctuations in water depth and a possible hiatus between the Early and the Late Pliocene are identified. Outside this area several hiatuses are also biostratigraphically identified in the Late Miocene, in the Early as well as in the Late Pliocene and at the PlioPleistocene boundary.
The Plio-Pleistocene boundary has been mapped and indicates a generally westward dipping surface (Huuse \& LykkeAndersen, 2000). In most places the boundary is seen as a discordance, probably an erosional discordance after regression caused by the first Northern Hemisphere glaciation (Figure 1). The maximum thickness of the Pleistocene in the Central Graben area is over $1000 \mathrm{~m}$. Here the boundary is also difficult to recognise in biostratigraphic analysis of the KIM-1 well (Konradi, 1995) and it is only indicated by the last occurrence of the foraminifer species Cibicides grossus generally said to belong in the Pliocene. The foraminifer species Elphidium oregonense characterises the first biostratigraphic zone in the Pleistocene (King, 1983, 1989). However, this species that belongs to the outer littoral facies has probably not been identified in the present well because of an unfavourable environmental setting in deep water. The species is found in several wells further south in the Danish sector (Pedersen, 1995) and onshore in the Netherlands (Van Voorthuysen, 1952).

\section{Pleistocene and Holocene}

The information on the Pleistocene is partly extracted from industrial reports from the hydrocarbon industry. These reports are concerned with the western-central part of the Danish sector. Seismically the Pleistocene consists of laterally continuous, sub-horizontal reflectors interpreted to be interbedded clay and sand sequences. Still, in a scientific borehole in the central-eastern part of the Danish sector, chiefly sands were identified. In these reports also several conspicuous reflectors are mentioned indicating several sedimentation events probably separated by erosion events (Konradi, 2002b).

Often the base of the Quaternary demonstrates the existence of valleys cut into that surface, caused by channelling, and most often repeated channelling in the Pleistocene. Part of these channels were thapped by conventional seismic techniques (Salomonsen, 1995), but other parts were mapped by high-resolution multichannel reflection seismic showing a general north-south trend (Huuse \& Lykke-Andersen, 2000). Part of the deeper seated channels are expected to correlate with the multiple channelling seen in the Central British sector (Stoker et al., 1985), even though the individual formations have not been identified in the Danish sector. Some of the upper channelling events in the western-central Danish sector have been biostratigraphically dated to the Late Pleistocene (Salomonsen \& Jensen, 1994) and correlated with nearby biostratigraphically dated boreholes.

Biostratigraphic analysis of boreholes in the Danish sector and adjacent British and Norwegian sectors indicate the existence of marine deposits with a temperate fauna. These can be ascribed to four interglacials (Sejrup \& Knudsen, 1993). The same applies to marine deposits identified onshore Denmark (Sejrup \& Knudsen, 1999) where these deposits are often found in depressions in the Quaternary subsurface. 
Only limited investigations are concerned specifically with the Holocene. In a scientific borehole located in an erosional channel, identified in seismic data beneath the outer Heligoland Channel (Konradi, 2000), a Holocene succession has been identified biostratigraphically. An account of the environmental development of the 'Elbe Urstromtal' and of the Heligoland Channel area in the eastern North Sea is also given. In cores from the above mentioned industrial reports on site survey investigations several Holocene formations were identified and tentatively correlated with the lithostratigraphy in the Dutch and British southern North Sea (Konradi, 2002a, 2003; Konradi \& Czakò, 2002a,b,c). Sediments correlatable with the late Pleistocene Twente Formation, the early Holocene Elbow Formation and the recent Nieuw Zeeland Gronden Formations were identified.

\section{References}

Cameron, T.D.J., Buat, J. \& Mesdag, C.S., 1993. High resolution seismic profile through a Late Cenozoic delta complex in the southern North Sea. Marine and Petroleum Geology 10: 591-599.

Deegan, C.E. \& Scull, B.J. (compilers), 1977. A proposed standard lithostratigraphic nomenclature for the Central and Northern North Sea. Report of the Institute of Geological Sciences No. 77/25.

Huuse, M., 2002. Late Cenozoic palaeogeography of the eastern North Sea Basin: climatic vs. tectonic forcing of basin margin uplift and deltaic progradation. Bulletin of the Geological Society of Denmark 49: 145-170.

Huuse M. \& Clausen, O.R., 2001. Morphology and origin of major Cenozoic sequence boundaries in the eastern Danish North Sea: top Eocene, near top Oligocene and the mid-Miocene unconformity. Basin Research 13: 17-41.

Huuse, M. \& Lykke-Andersen. H., 2000. Overdeepened Quaternary valleys in the eastern Danish North Sea: morphology and origin. Quaternary Science Reviews 19: 1233-1253.

King, C., 1983. Cainozoic micropalaeontological biostratigraphy of the North Sea. Institute of Geological Sciences Report 82/7: $40 \mathrm{pp}$.

King. C., 1989. Cenozoic of the North Sea. In: Jenkins, D.G. \& Murray, J.W. (eds): Stratigraphical atlas of fossil foraminifera (2nd ed.). Chichester (Ellis Horwood Ltd.): 418-489.

Konradi, P.B., 1995. Foraminiferal biostratigraphy of the post mid-Miocene in two boreholes in the Danish North Sea. Geological Survey of Denmark Series C No. 12: 101-112.

Konradi, P.B., 1996. Foraminiferal biostratigraphy of the post-mid-Miocene in the Danish Central Trough, North Sea. In: De Batist, M. \& Jacobs, P. (eds): Geology of Siliciclastic Shelf Seas. Geological Society Special Publication (London) 117: 15-22.

Konradi, P.B., 2000. Biostratigraphy and environment of the Holocene marine transgression in the Heligoland Channel, North Sea. Bulletin of the Geological Society of Denmark 47: 71-79.

Konradi, P., 2002a. Description of seven vibrocores from the Lille Fisker Banke area, Danish North Sea. Danmarks og Grønlands Geologiske Undersøgelse Rapport 2002/38: 27 pp.

Konradi, P., 2002b. Review of site surveys, Store Fiske Banke area, Danish North Sea. Danmarks og Grønlands Geologiske Undersøgelse Rapport 2002/66: 32 pp.
Konradi, P., 2003. Description of vibrocores from four well sites in the Danish North Sea. Danmarks og Grønlands Geologiske Undersøgelse Rapport 2003/75: $58 \mathrm{pp}$.

Konradi, P. \& Czakó, T., 2002a. Geological description of vibrocores from the Nini-3 site, Store Fisker Banke area, Danish North Sea. Danmarks og Grønlands Geologiske Undersøgelse Rapport 2002/2: 39 pp.

Konradi, P. \& Czakó, T., 2002b. Geological description of six vibrocores from the Hejre-1 site, Store Fisker Banke area, Danish North Sea. Danmarks og Grønlands Geologiske Undersøgelse Rapport 2002/32: 39 pp.

Konradi, P. \& Czakó, T., 2002c. Geological description of five vibrocores from the South Pod site, Store Fisker Banke area, Danish North Sea. Danmarks og Grønlands Geologiske Undersøgelse Rapport 2002/41: 29 pp.

Kristoffersen, F.N. \& Bang, I., 1982. Cenozoic excl. Danian Limestone. In: Michelsen, 0. (ed.), 1982. Geology of the Danish Central Graben. Geological Survey of Denmark Series B, No. 8, 62 - $71 \mathrm{pp}$.

Michelsen, O., 1996. Late Cenozoic basin developement of the eastern North Sea Basin. Bulletin of the Geological Society of Denmark 43: 9-21.

Michelsen, O., Thomsen, E., Danielsen, M., Heilmann-Clausen, C., Jordt, $H$. \& Laursen, G.V., 1998. Cenozoic sequence stratigraphy in the eastern North Sea. Society for Sedimentary Geology (SEPM) Special Publication 60: 91-118.

Pedersen, A.M., 1995. The lower Pleistocene in The North Sea. Danmarks Geologiske Undersøgelse Series C, No. 13: 28 pp.

Rasmussen, L.B., 1966: Molluscan faunas and biostratigraphy of the marine younger Miocene formations in Denmark. Danmarks Geologiske Undersøgelse Series 2, No. 88: $358 \mathrm{pp}$.

Salomonsen, I., 1995. A seismic stratigraphic analysis of Lower Pleistocene deposits in the western Danish sector of the North Sea. Geologie en Mijnbouw 72: 349-361.

Salomonsen, I. \& Jensen, K.A., 1994. Quaternary erosional surfaces in the Danish North Sea. Boreas 23: 244-253.

Sejrup, H.P. \& Knudsen. K.L., 1993. Paleoenvironments and correlations of interglacial sediments in the North Sea. Boreas 22: 223-235.

Sejrup, H.P. \& Knudsen, K.L., 1999. Geochronology and paleoenvironment of marine Quaternary deposits in Denmark: new evidence from northern Jutland. Geological Magazine 135: 561-578.

Stoker, M.S., Long, D. \& Fyfe, J.A., 1985. A revised Quaternary Stratigraphy for the central North Sea. British Geological Survey Report 17(2): $35 \mathrm{pp}$.

Sørensen, J.C. \& Michelsen, O., 1995. Upper Cenozoic sequences in the southeastern North Sea Basin. Bulletin of the Geological Society of Denmark 42: 74-95.

Van Voorthuysen, J.H., 1952. Elphidium oregonense Cushman and Grant, a possible marker for Amstellian (Lower Pleistocene) in North America and northwestern Europe. Contribution from the Cushman foundation for foraminiferal research. 3: 22-23. 